ISSN : 2087-2461

PENANGGUNG JAWAB Dekan FIKOM

Trimanah, M.Si.

Sekretaris Dekan

Dian Marhaeni K, M.Si

Ketua Penyunting Made Dwi Adnjani, M.Si

Sekretaris

Mubarok, M.Si

Bendahara

Umi Hidayah, S.H.

Dewan Penyunting

Trimanah, M.Si

Edi Ismoyo, M.Si

Suharyoso, S.Sos

Seksi Usaha

Endang Winarsih, S.Sos

Sirkulasi dan Distribusi

Novi, S.Sos

Alamat Redaksi

Fakultas Ilmu Komunikasi

Universitas Islam

Sultan Agung Semarang

Jl. Raya Kaligawe Km. 4

Po. Box 1054/SM

Semarang 50112

Telp. (024) 6583584

ext. $448 / 449$

Fax. (024) 6582455

email : jurnalfikom@yahoo.com
Inovasi Digital Public Relations Pada

Perguruan Tinggi Swasta di Kota Semarang

dalam Meningkatkan Citra

Agus Triyono

agustriyono7@gmail.com

119-126

Eksistensi Buruh Dalam Komunikasi Bipartit

(Upaya Membangun Kemitraan Antara

Buruh dan Pengusaha Secara Ideal di Kota Kretek)

Muhammad Zakki Mubarok

$127-139$

Implementasi Konsep Diri Pada Kelompok Gemes

(Gemuk Menawan Semarang)

Kajian Teoritis Psikologi Komunikasi tentang

Konsep Diri Pada Kelompok Gemes

(Gemuk Menawan Semarang)

Genta Maghvira

140-149

Representasi Perempuan dalam

Film Cinta Suci Zahrana

Urip Mulyadi

$150-158$

Kapitalisme, Budaya Dunia, Internasionalisasi Bahasa dan Nilai-Nilai Islam Pada Tayangan Periklanan Anak di Media Televisi Dalam Perspektif Bidang Kreatif Industri Periklanan

Dian Marhaeni Kurdaningsih

marhaeni@unissula.ac.id

159-172

Paparan Media Promosi Kesehatan

Dengan Pengetahuan Pencegahan Infeksi

Bagi Pengunjung Rumah Sakit

Besar Tirto Husodo

e-mail : besarundip4@gmail.com

Puspa Run Canti

173-177

Model Kampanye Pilkada Atasi Politik Uang

dan Sikap Pesimis Pemilih

(Telaah teoritis dan konsep implementasinya)

Hariyani

nhyani812@gmail.com

178-193 


\title{
KAPITALISME, BUDAYA DUNIA, INTERNASIONALISASI BAHASA DAN NILAI-NILAI ISLAM PADA TAYANGAN PERIKLANAN ANAK DI MEDIA TELEVISI DALAM PERSPEKTIF BIDANG KREATIF INDUSTRI PERIKLANAN
}

\author{
Dian Marhaeni Kurdaningsih \\ Universitas Islam Sultan Agung \\ marhaeni@unissula.ac.id
}

\begin{abstract}
Abstrak
Penelitian ini bersifat lanjutan dari kajian sebelumnya yang dilakukan oleh peneliti dalam mengkritisi media. Kajian tentang wacana kapitalis dalam iklan anak, internasionalisasi bahasa periklanan anak, iklan anak dan etika media, iklan makanan dan minuman ditinjau dari perspektif kearifan lokal, menghasilkan simpulan bahwa telah terjadi praktek kapitalis, internasionalisasi bahasa, pengunaan budaya dunia, dan pelanggaran etika dalam karya kreatif iklan. Disisi lain Periset kali ini lebih fokus mengungkap pandangan departemen kreatif periklanan sebagai pihak yang bertanggung jawab terhadap karya naskah iklan. Bagaimana insan departemen kreatif memahami isu-isu ideologi dunia dan pengaruhnya terhadap karya iklan.

Penggalian data dilakukan secara wawancara mendalam dengan prosedur penelitian kualitatif deskriptif model Milles dan Habermen. Penentuan informan dilaksanakan secara purposive sesuai dengan tujuan penelitian. Kualitas data dilakukan dengan trianggulasi sumber penelitian, dimana prosedur ini menuntut peneliti untuk mericek data penelitian yang sudah terkumpul. Trianggulasi juga dilakukan secara teori, dimana setiap statemen didukung oleh teori yang kualified.

Analisis penelitian didukung oleh teori jurnalistik yang mempengaruhi isi media dan etika media. Al Quran Al Karim dimana Nilai-nilai Islam tentang etika media dicantumkan secara detail. Penelitian ini menghasilkan simpulan bahwa faktor internal berupa sumber daya insani sangat mempengaruhi isi dan kualitas karya insan departemen kreatif periklanan. Faktor ideologi, agama, pendidikan, kreatifitas berpengaruh dalam menuangkan monsep iklan.

Saran penelitian, penting melakukan pemahaman pendidikan, ajaran agama, kreatifitas yang bertanggung jawab agar karya ideal insan kreatif tidak jatuh mengikuti ambisi kapitalis.
\end{abstract}

Kata kunci: Kapitalisme iklan, internasionalisasi bahasa, nilai-nilai Islam, Iklan Anak.

\section{A. PENDAHULUAN}

Televisi di kalangan masyarakat Indonesia sudah berfungsi layaknya teman dalam keluarga. Ada beberapa hal yang membuat iklan televisi ini sangat menarik bagi pemirsanya. Selain memberi informasi tentang produk, menampilkan gaya hidup masa kini, dan juga menghibur, iklan televisi menampilkan tokoh atau bintang iklan yang memiliki karakter khas sebagai idola bagi pemirsa. Begitu juga tema dan ide iklan itu sendiri merupakan fenomena kehidupan sehari-hari yang dekat dengan harapan masyarakat. Sebagai contoh kehidupan keluarga yang harmonis, remaja aktif, anakanak sehat ceria dan orang tua lengkap dengan atribut yang menyiratkan pola kehidupan masa kini yang serba moderen dan mudah.

Televisi adalah salah satu media yang mempunyai keunggulan dalam periklanan, karena televisi mempunyai daya tarik yang disebabkan unsur kata-kata, musik dan efek suara. Selain ketiga unsur tersebut, televisi juga memiliki unsur visual berupa gambar. Bukan gambar mati melainkan gambar hidup yang mampu menimbulkan kesan mendalam 
dan daya tarik kepada para pemirsanya (Effendi, 2000.hal:177).

Pendapat ini juga dipertegas oleh Raymond Williams dan Simon During yang dikutip Burhan Bungin, kedua pakar ini kagum terhadap iklan dilandasi dasar yang kuat. Televisi telah mengangkat medium iklan ke dalam konteks yang sangat kompleks namun jelas, berimajinasi namun kontekstual, penuh dengan fantasi namun nyata (Bungin, 2001, hal:122).

Salah satu fenomena tayangan iklan televisi yang menarik adalah iklan anak. Iklan anak adalahiklanyang menampilkananak-anak sebagai bintang iklan atau melibatkan mereka sebagai icon dalam menyampaikan pesanpesan komersial iklan. Anak-anak muncul sebagai bintang iklan untuk menyampaikan pesan produk yang dikonsumsi oleh anak-anak seperti susu, obat-obatan, permen, makanan kemasan, minuman ringan, mainan, peralatan sekolah, kosmetik anak, tempat wisata dan sebagainya. Karena kemunculan tokoh anak, tidak hanya menyampaikan pesan iklan untuk produk anak. Beberapa iklan dengan target market orang dewasa juga menggunakan tokoh anak-anak untuk menyampaikan pesan komersial. Sebagai contoh iklan produk elektronik, iklan mobil, iklan perumahan, iklan cat tembok, iklan pembasmi serangga dan sebagainya.

Munculnya anak-anak pada iklan televisi sekaligus memperlihatkan gambaran yang kuat tentang gaya hidup moderen, yang serba baru, indah dan tidak ketinggalan zaman. Tayangan ini juga menyiratkan ciri khas kehidupan masyarakat yang memiliki kelas tertentu yaitu orang-orang kaya atau golongan The have. Tayangan iklan anak dinilai oleh orang tua dan guru, serta aktifis LSM perlindungan anak telah melenceng dari fungsi semula yaitu menyampaikan informasi yang benar tentang produk kepada anak dan orang tua. Anak-anak dengan sengaja dilibatkan dalam iklan dengan tujuan tertentu dari pemilik produk untuk menarik simpatik di kalangan anak-anak dan orang tua.

Pada kenyataannya iklan anak dinilai telah menampilkan eksploitasi anak bagi kepentingan media, pasar, perusahaan, dan kapitalis. Anak-anak dieksploitasi untuk mendapatkan keuntungan dengan cara melibatkan mereka dalam menyampaikan pesan produk-produk orang dewasa yang belum dipahaminya. Anak-anak juga tampil menyuarakan gaya hidup kelas tertentu yang berarti mengajarkan perpecahan dengan pola hidup terkotak-kotak. Telah terjadi eksploitasi anak-anak dengan melibatkan mereka sebagai bintang iklan untuk produk yang belum dipahami mereka. Anak dimanfaatkan oleh kalangan kapitalis sebagai sarana meraup keuntungan sebanyak-banyaknya atau penumpukan modal (Marhaeni, 2005,hal:125). Inilah apa yang peneliti maksud dengan kapitalisme anak-anak dalam iklan.

Kapitalisme adalah suatu paham atau ajaran yang bisa menjadi bumerang bagi anakanak. Karena paham ini mengajarkan nilainilai baru yang pada dasarnya bertentangan dengan budi pekerti yang ditanamkan orang tua selama ini. Menurut ajaran Calvinisme Weber, kapitalisme harus mampu mengatasi sikap-sikap tradisional dan mengedepankan realitas, hal ini tercermin jelas pada iklan. Iklan menggeser sikap-sikap tradisional seperti hemat, sederhana, kedalam sikap hedonis yang mengutamakan belanja. Dipertegas juga oleh Stuart Ewen seperti dikutip Ratna Noviani bahwa norma-norma tradisional seperti puritan, asketis, hemat, sabar, tabah, pantang menyerah mengalami keruntuhan di era industri (Ratna, 2002, hal: 17).

Iklan anak juga mengandung unsur pencabutan kearifan lokal. Budaya yang berakar dari nilai-nilai luhur bangsa Indonesia melalui pengetahuan, sikap dan perilaku yang dilandasi nilai-nilai lokal telah tercabut. Iklan adalah salah satu tayangan yang mampu mensosialisaikan dn menciptakan budayabudaya baru yang kurang mengindonesia.

Selain itu iklan anak sinyalir juga mensosialisan bahasa internasional khususnya untuk mempromosikan produk-produk lokal. Mengikis kebiasan lokal anak yang baik, mendidik dan alami yang tergantikan dengan budaya baru, budaya bahasa internasional di kalangan anak-anak. 
Anak-anak sebagai penerus generasi bangsa diharapkan mampu mandiri dan tetap menjaga persatuan dan kesatuan bangsa. Usia anak-anak adalah masa-masa paling sensitif dalam pembentukan pikiran dan pribadi anak. Di usia ini anak sangat mudah terpengaruh pikiran atau prilaku lingkungan sekitarnya. Tidak terkecuali oleh tayangan iklan televisi, dan tayangan umum yang penontonnya juga anak-anak.

Bimbingan orang tua sangat dibutuhkan dalam mendampingi anak-anak ketika menonton siaran televisi khususnya iklan anak. Meskipun tayangan tersebut pada waktu tertentu dikhususkan untuk menyampaikan pesan kepada anak tetapi isi pesannya sendiri sering tidak mendidik. Untuk kepentingan komersial, acara televisi sengaja dikemas untuk memenuhi selera pasar dan memenuhi target iklan. Ditinjau dari nilainilai Islam, orang tua memiliki kewajiban agar putra putri mereka menjadi anak yang mulia. Islam mengajarkan agar anak-anak didik untuk patuh dan tidak menyekutukan Allah SWT. (Al Quran Surat Lukman(31):13)

Diperlukan sikap dan tanggapan yang positif bagi orang tua untuk membimbing anak-anak berperilaku bijak. Atau bagaimana orang tua dituntut untuk mendidik anak yang berkarakter mulia. Allah memerintahkan kepada manusia untuk mendidik putra putri mereka seperti yang tertulis dalam Al Quran Surat Al Luqman. Diantara perintah tersebut adalah perintah tidak mempersekutukan Allah SWT, berbakti kepada orang tua, berbuat kebaikan kepada orang tua. Islam juga mengajarkan bahwa semua perbuatan akan mendapat balasan sehingga anak-anak wajib diajarkan untuk rajin beribadah, beramal baik, mencegah perbuatan buruk, bersabar dan tidak sombong.

Faktor sosial ekonomi masyarakat atau keluarga yang berhubungan signifikan dengan pendidikan orang tuamerupakan saranapenting dalam membangun sikap dan tanggapan terhadap konten media, yang nantinya akan diteruskan untuk mengarahkan dan mendidik anak-anak mereka. Tingkat sosial ekonomi yang sudah mandiri menciptakan perhatian yang positif orang tua kepada kegiatan anak. Orang yang berpendidikan rendah jarang membaca surat kabar, tetapi sering menonton televisi.Eksekutifdan kaum bisnis menyenangi rubrik niaga dalam surat kabar atau majalah. Telah diteliti bahwa kelompok menengah atau middle class cenderung menyukai acara pendidikan, berita dan informasi (Jalaluddin Rakhmat,1991,hal: 2004).

Iklan dirancang oleh seorang penulis naskah iklan pada sebuah industri periklanan. Penulis naskah iklan atau disebut copy writer yang bekerja pada bagian departemen kreatif. Departemen kreatif dipimpin oleh pengarah kreatif atau disebut Art Director. (Budiman Hakim, 2008:37) Pada penelitian ini pendahulu, makna komunikasi yang berhubungan dengan pesan iklan ataupun makna tayangan iklan secara keseluruhan, aspek kreatif ini jarang disentuh. Departemen kreatif adalah pihak yang bertanggung jawab dalam merancangan karya iklan. Pesan-pesan yang kemudian diberi makna oleh peneliti mengandung pesan-pesan yang kurang mendidik bagi anak seharusnya dipahami juga oleh perancang iklan. Akan tetapi pada kenyataannya pahamkah insan kreatif periklanan ini bahwa iklan yang diciptakannya sudah mengandung pesan-pesan yang kurang baik bagi anak. Terutama jika dipandang dari perspektif nilai-nilai Islam.

Penelitian sebelumnya tentang kapitalisme pada iklan anak telah diteliti oleh Dian Marhaeni K, dengan judul "Wacana Kapitalis dalam Iklan Anak-Anak di Media Televisi, Analisis Wacana" menghasilkan kesimpulan bahwa telah terjadi praktek kapitalisme di kalangan anak-anak pada tayangan iklan anak di media televisi. Penelitian lanjutan tentang budaya dunia dan kearifan lokal dengan judul Iklan makanan dan minuman pada pada tayangan iklan anakanak di televisi dalam perspektif kearifan lokal menyimpulkan bahwa tayangan iklan anak menyampaikan pesan-pesan budaya dunia atau budaya baru yang sudah mencabut kearifan lokal nilai-nilai budaya Indonesia yang luhur. Iklan anak-anak juga diteliti oleh Dian (Dian, 2013) bahwa telah terjadi 
internasionalisasi bahasa periklanan anak pada iklan anak di televisi. Untuk itu peneliti pada penelitian kali ini ingin kembali mengungkap permasalahan kapitalis pada iklan anak-anak di media televisi, yaitu bagaimana pesan-pesan iklan tersebut jika dipandang dari perspektif departemen kreatif sebuah industri periklanan.

Adanya fenomena pesan-pesan iklan pada tayangan iklan anak-anak di media televisi membutuhkan perspektif yang berbeda. Inti dalam penciptaan sebuah iklan adalah pada bidang kreatif industri komunikasi. Penting bagi masyarakat memahami kinerja bidang kreatif sebuah biro iklan. Insan departemen kreatif adalah pihak yang bertanggung jawab dengan munculnya pesan-pesan iklan di televisi. Permasalahan tersebut menjadi masalah pokok yang akan dikaji dalam penelitian ini yaitu:

a. Bagaimana pemahaman proses perancangan pesan kapitalisme pada departemen kreatif industri periklanan

b. Bagaimana pemahaman proses perancangan pesan budaya dunia pada departemen kreatif industri periklanan

c. Bagaimana pemahaman proses perancangan pesan internasionalaisasi bahasa pada departemen kreatif industri periklanan

d. Bagaimana pemahaman nilai-nilai Islam pada insan departemen kreatif industri periklanan.

Penelitian ini memiliki cakupan yang luas dalam variabel yang akan diteliti maka peneliti membatasi permasalahan pada :

a. Bidang kreatif yang dimaksud dalam penelitian ini adalah bidang penulis naskah iklan (copywriter), perancang gambar (visualiser), dan pengarah seni (art direktor) yang bekerja dalam sebuah industri periklanan di Indonesia.

b. Insan bidang kreatif sebagai subjek penelitian yang dimaksud dalam penelitian ini adalah bidang kreatif di industri periklanan yang merancang dan memproduksi iklan televisi. c. Nilai-nilai Islam adalah mengacu pada QS Al Luqman

\section{B. METODOLOGI}

\section{a. Tahapan Penelitian}

Berdasarkan masalah yang diajukan dalam penelitian ini pemahaman kapitalisme, budaya dunia, dan internasionalisasi bahasa perikalanan, maka jenis penelitian dengan strateginya yang terbaik adalah penelitian kualitatif deskriptif verifikatif. Format penelitian kualitatif verifikatif mengkonstruksi format penelitian dan strategi untuk lebih awal memperoleh data sebayak-banyaknya di lapangan, dengan mengesampingkan peran teori, walaupun demikian teori tetap menjadi hal penting dalam format ini. Dengan demikian dalam penelitian ini peran data lebih penting daripada teori (Bungin,2007, hal:147).

Adapun strategi yang digunakan mengutip langkah dari Seiddel (Sutopo, 2002, hal: 33), sebagai berikut :

1) Mencatat yang menghasilkan catatan lapangan, dengan hal itu diberi kode agar sumber datanya tetap dapat ditelusuri;

2) Mengumpulkan, memilah-milah, mengklasifikasikan, menyintesiskan, membuat ikhtisar, dan membuat indeksnya.

3) Berpikir, dengan jalan membuat agar kategori data itu mempunyai makna, mencari dan menemukan pola, dan hubungan-hubungan; dan

4) Membuat temuan-temuan umum. 


\section{Kerangka Pikir}

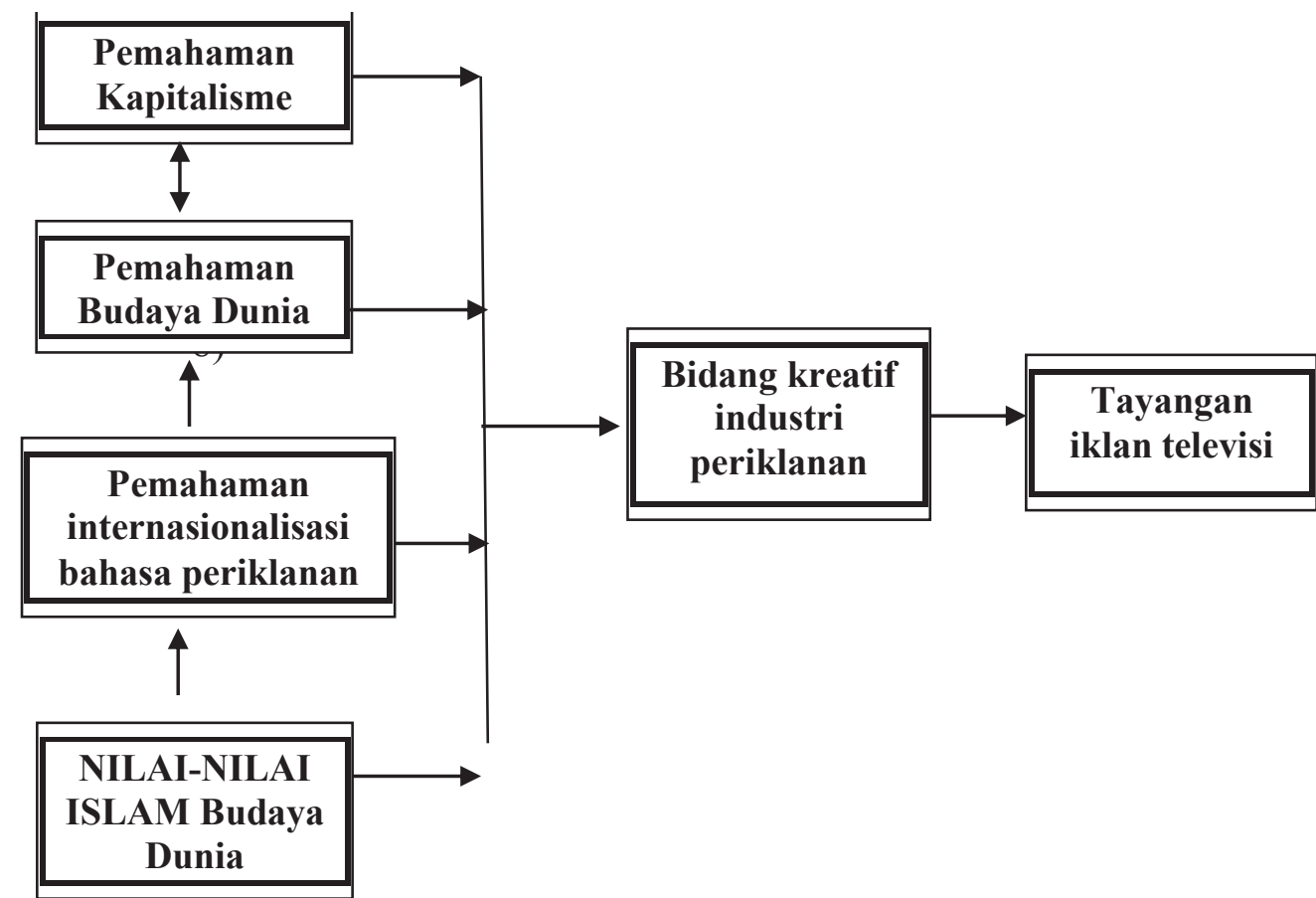

\section{b. Sumber data}

Data atau informasi yang paling penting untuk dikumpulkan dan dikaji dalam penelitian ini sebagian besar berupa data kualitatif. Informasi diperoleh dan dikaji dari beberapa sumber data dan jenis sumber data yang akan digunakan dalam penelitian ini meliputi:

Data primer

Data primer dalam penelitian ini diperoleh dari:

1) Informan atau narasumber adalah insan bisang kreatif industry periklanan yang terdiri dari copywriter, visualizer dan art director.

1) Dokumen yaitu hasil rekam tayangan iklan televisi yang memuat unsur kapitalis, budaya dunia dan internasionalisasi bahasa periklanan.

Data sekunder

Data sekunder dalam penelitian ini diperoleh dari:

1) Kegiatan atau aktivitas kerja insan bidang kreatif industri periklanan.
2) Arsip dan dokumen resmi media televisi, data-data iklan industri periklanan sebagai objek penelitian ini.

c. Teknik analisis dan pengumpulan data

Teknik analisis akan dilakukan dengan menggunakan model analisis interaktif (Miles \& Huberman, dalam Sutopo, 2002, hal: 186). Dalam model analisis ini, tiga komponen analisisnya yaitu reduksi data, sajian data, dan penarikan simpulan atau verifikasinya, aktifitasnya dilakukan dalam bentuk interaktif dengan proses pengumpulan data sebagai proses siklus. Reduksi data merupakan proses seleksi, pemfokusan, penyederhanaan dan abstraksi data dari catatan lapangan. Proses ini berlangsung selama pelaksanaan penelitian. Reduksi data dilakukan dengan membuat ringkasan dari catatan lapangan. Peneliti juga membuat koding, memusatkan tema, menentukan batas-batas permasalahan, dan juga menulis memo.

Pada sesi sajian data, merupakan suatu rakitan organisasi informasi, deskripsi dalam bentuk narasi yang 
memungkinkan simpulan penelitian dapat dilakukan. Sajian data selain dalam bentuk narasi kalimat, juga matriks, gambar atau skema, jaringan kerja keterkaitan kegiatan dan tabel. Adapun simpulan dan verifikasi dilakukan sejak awal pengumpulan data dengan melakukan pencatatan peraturan-peraturan, pola-pola, pernyataan-pernyataan, konfigurasi yang mungkin, arahan sebab akibat dan berbagai proposisi. Simpulan perlu diverifikasi agar benar-benar bisa dipertanggungjawabkan dengan dilakukan aktivitas pengulangan untuk tujuan pemantapan, penelusuran data kembali dengan cepat atau dilakukan diskusi.

Dalam melakukan proses siklus ini peneliti aktivitasnya tetap bergerak di antara komponen analisis dengan pengumpulan datanya selama proses pengumpulan data masih berlangsung. Kemudian peneliti hanya bergerak di antara tiga komponen analisis tersebut sesudah pengumpulan data selesai.

\section{d. Teknik Pengumpulan Data}

Maka sesuai dengan bentuk penelitian kualitatif dan juga jenis sumber data yang dimanfaatkan, teknik pengumpulan data yang akan digunakan dalam penelitian ini adalah

1) Wawancara mendalam (in-depth interviewing)

2) Observasi langsung

3) Mencatat dokumen (Content analysis)

\section{e. Teknik Cuplikan (Sampling)}

Penelitian kualitatif cenderung menggunakan teknik cuplikan yang bersifat selektif dengan pertimbangan berdasarkan konsep teoritis yang digunakan, keingintahuan pribadi peneliti, karakteristik empirisnya, dan lain-lain. Oleh karena itu bersifat "purposive sampling", atau cuplikan "criterion-based selection" (Goetz \& LaComte dalam Sutopo, 2002, hal:185). Dalam hal ini peneliti akan memilih informan yang dipandang paling tahu, sehingga kemungkinan pilihan informan dapat berkembang sesuai dengan kebutuhan dan kemantapan peneliti dalam memperoleh data (Patton, dalam Sutopo, 2002, hal: 185).

Cuplikan sepertiinilebih cenderung sebagai "internal sampling" (Bogdan \& Biklen, dalam Sutopo, 2002, hal:185) yang memberi kesempatan bahwa keputusan bisa diambil begitu peneliti memiliki pikiran umum yang muncul mengenai apa yang sedang dipelajari, dengan siap akan berbicara, kapan perlu melakukan observasi yang tepat atau time sampling, dan juga jumlah dokumen yang akan diteliti.

\section{f. Validitas Data}

Untuk menjamin dan mengembangkan validitas data yang akan dikumpulkan, dalam penelitian kualitatif ini menggunakan teknik validitas data yaitu teknik trianggulasi. Dari empat macam teknik trianggulasi, yang meliputi trianggulasi data, trianggulasi peneliti, trianggulasi metodologis, dan trianggulasi teoretis, (Patton, dalam Sutopo, 2002, hal:186) akan digunakan trianggulasi data atau trianggulasi sumber. Dipilih cara ini karena mengarahkan peneliti agar dalam mengumpulkan data, ia wajib menggunakan beragam sumber data yang tersedia. Artinya data yang sama atau sejenis akan lebih mantap kebenarannya bila digali dari beberapa sumber data yang berbeda.

Dalam teknik trianggulasi sumber ini, nantinya juga bisa menggunakan satu jenis sumber data misalnya informan, namun beberapa informan atau narasumber yang digunakan harus merupakan kelompok atau tingkatan yang berbeda-beda. Trianggulasi sumber yang memanfaatkan jenis sumber data yang berbeda-beda, tekanannya adalah pada perbedaan sumber data bukan pada teknik pengumpulan data. Cara trianggulasi 
sumber yang lain dapat dilakukan dengan menggali informasi dari satu nara sumber tertentu, dari kondisi lokasinya, dari aktivitas yang menggambarkan perilaku orang atau warga masyarakat atau dari sumber yang berupa catatan atau arsip dan dokumen yang memuat catatan yang berkaitan dengan data yang dimaksudkan peneliti ( Sutopo, 2002, hal: 79).

\section{g. Prosedur Kegiatan}

Kegiatan penelitian ini seluruhnya direncanakan sebagai berikut:

a. Persiapan

b. Pengumpulan data

c. Analisis data

d. Penyusunan laporan penelitian

\section{PEMBAHASAN}

1. Identitas individu, nama, tempat, tanggal lahir, pendidikan, alamat, pekerjaan berpengaruh dalam membentuk kerangka berpikir insan departemen kreatif periklanan

Nama suku tertentu (Jawa) beserta perangkat dan filosofi budayanya mempengaruhi informan dalam berprinsip, bertutur dan bagaimana memahami hidup. Seperti pendapat Shoemaker bahwa faktor individual inilah yang mampu mempengaruhi isi media termasuk iklan.

Lokasi dan era informan hidup yang diliputi gejolak dunia politik dan ekonomi di masa orde baru, krisis dan pergerakan pemuda mempengaruhi idealism informan dalam berkarya. Faktor individual yang ditekankan Shoemaker membenarkan bahwa faktor individual berperanan penting dalam mempengaruhi isi media massa yang dalam hal ini iklan.

Pusatmedia di propinsi, pusat bisnis dan kegiatan dimana dilingkungkan informan tinggal, mempengaruhi dalam kreatifitas mengembangkan ideide iklan. Semakin banyak kegiatan bisnis memungkinkan sekali berimbas pada iklan. Insan departemen kreatif dituntut untuk selalu memiliki ide baru dalam mengembangkan karyanya. Peluang strategi pemasaran dan periklanan mau tidak mau ditangani dengan pemaksaan kreatifitas yang beda dari masing-masing permintaan klien.

Faktor pendidikan informan yang kuliah di Perguruan Tinggi Negeri dengan tradisi dan idealism akademik yang kuat mempengaruhi dalam pemahaman isme-isme dan secara tidak langsung mempengaruhi informan dalam berkarya. Faktor nilainilai agama, pendidikan adalah salah satu faktor individual yang sangat berpengaruh pada isi media seperti pernyataan Pamela J Shoemaker.

Pendidikan di Universitas Diponegoro merupakan contoh lima besar deretan universitas ternama di Indonesia berdasarkan urutan dari berbagai sumber seperti Dikti dan LIPPI, Sebagai universitas terbaik sangat menjunjung tinggi idealisme keilmuan. Para dosennya dibekali dengan etika akademik yang tinggi sehinga mampu mengajarkan dengan kualitas terbaik kepada mahasiswanya. Universitas Diponegoro merupakan universitas negeri miliki pemerintah yang tentu saja beridealisme nasional, tidak berideologi agama.

Ideology merujuk konsep Raymond William adalah Sistem kepercayaan yang dimiliki oleh kelompok atau kelas tertentu. Definisi ini dipakai oleh kalangan psikologi yang melihat ideologi sebagai seperangkat sikap yang dibentuk dan diorganisasikan dalam bentuk yang koheren. Nilai-nilai perguruan tinggi infoman inilah yang mungkin tanpa disadari sesungguhnya sudah merasuki dan mewarnai idealisme informan dalam mengambil keputusan. Sesuai pendapat Shoemaker bahwa 
ideologi pemerintah yang berkuasa, ideologi lembaga yang merupakan panjang tangan pemerintah, akan mempengaruhi isi media.

Sejak kuliah informan sudah mencoba berkarir sebagai praktisi periklanan dengan menerima order untuk mendesain dan memproduksi sendiri iklan yang menjadi pesanan kliennya. Informan juga melakukan sendiri praktik kegitan presentasi, lobbi dan negosiasi untuk mendapatkan projek dari para kliens. Kemampuan ini diperoleh dari bekal selama menuntut ilmu di fakultas Ilmu Komunikasi Undip.

Setelah lulus kuliah informan mencoba peruntungan di Jakarta, ibukota Negara Indonesia, pusat perekomian Negara dengan jumlah 255 juta jiwa. Melanglang beberapa tahun di ibukota sebagai praktisi periklanan di beberapa perusahaana ternama di Jakarta, informan memutuskan kembali ke Semarang dan membangun perusahaan sendiri setelah 5 tahun sebagai praktisi yang bekerja dibawah perusahaan orang lain.

Dalam kiprahnya sebagai praktisi informan berkecimpung langsung dalam penciptaan karya iklan baik itu iklan media televisi, iklan surat kabar dan iklan media luar ruang. Beberapa iklan audio visual dan iklan televisi pernah dirilisnya. Beberapa klien memberi tanggung jawab kepada informan hingga perhitungan istilah yang familiar di bidang periklanan adalah media planner. Salah satu hal penting adalah bahwa sebagai professional di industry periklanan informan dituntun menguasai dan mumpuni di bidang periklanan. Terutama adalah ketrampilan bidang kreatif industry periklanan. Beberapa iklan media audio visual dan iklan televisi pernah beberapa waktu di desain dan diproduksinya.

Patner keluarga yang satu almamater yaitu alumnus universitas
Diponegara bertekad membangun sendiri perusahaannnya. Diberilah nama perusahaan iklan ini dengan nama PT Elang Reklamedia. Sebagai owner dan praktisi berpengalaman informan juga diminta sharing dengan memberi mata kuliah tamu di bidang periklanan di beberapa perguruan tinggi. Faktor keluarga yaitu suami berperanan penting dalam keluarga apalagi bagi istri, secara psikologi seorang istri mau tidak mau pemikiran suami akan mempengaruhi keputusannya dalam hidup. Dan dalam pekerjaan ataupun menjalankan profesi di bidang kreatif ide dan saran banyak arahkan, diberi masukan, berdasarkan usulan dari suami.

Faktor peer group, komunitas, kelompok primer yang melingkupi informasn dalam hal ini lingkungan individual ataupun ekstra media berpengaruh dalam menentukan isi media.

2. Afiliasi agama, politik, ideology, mempengaruhi individu dalam menciptakan kerangka pikir dalam berkarya

Keyakinan seseorang dalam hal ini agama, mengajarkan bagaimana umatnya hidup dengan menggunakan nilai-nilai Islam dalam pedoman hidupnya secara kaffah (sempurna). Contoh individu yang berkeyakinan Islam akan senantiasa memasukkan nilai-nilai Islam ke dalam seluruh sendi kehidupannya. Islam tidk memisahkan ajarannya dengan kehiduan umatnya. Segala tindak tutur, sikap, hati dan pemikiran selalu terwarnai keIslamannya. Oleh karena itu dalam berkarya seorang praktisi komunikasi jika berpedoman dengan nilai-nilai Islam akan secara langsung maupun tidak terwarnai dalam karyakaryanya. Demikian juga dengan praktisi periklanan yang bekerja dalam departemen kreatif. Desain kreatif karya iklan tercipta tidak dengan 
sendirinya hanya berdasarkan pada ide kreatif semata. Namun terkait langsung dengan kualitas individu sebagai insan departemen kreatif. Karya iklan yang kreatif, menarik, lucu, bagus, focus, adalah karya seorang insan departemen kreatif yang terlibat langsung penciptaan iklan yang sudah sangat dipengaruhi aspek individualnya terutama faktor agama dan keyakinan.

Informan tidak terlibat langsung dengan afiliasi politik tertentu. Ini terbukti karena informan bukan aktifis, partisipatif maupun kader sebuah partai politik. Namun bila ditanya tentang kebijakan politik partai atau ormas tertentu informan akan menjawab secara netral. Netral dalam hal ini tentu bermakna logis. Artinya jika ada kebijakan yang baik yang pro dengan rakyat informan akan setuju dan mendukung meskipun tidak memandang dari partai mana atau organisasi massa manapun. Orientasi ini akan berpengaruh pada keputusan informan yang tidak terlalu ketat atau mengikuti norma umum dalam perancangan karya

Kalau dilihat dari nama informan bukan dari kalangan pesantren atau dari kalangan agamis. Meskipun begitu orientasi keyakinan informan adalah Islam, karena agama informan adalah Islam. Orientasi ini akan terus menggiring kepada informan dalam berpikir, bersikap dan berperilaku sesuai dengan petunjuk nilai-nilai Islam. Informan adalah muslim yang taat, yang diketahui dari sholat lima waktu yang tepat waktu, berpuasa wajib, menjaga makan minum yang halal, berbusana Islami dan menjaga harta dengan kehalalannya. Tentu saja faktor individual yang berupa agama paling tidak akan membatasi dalam berkreatifitas, atau kreatifitas dengan batas-batas yang tidak bertentangan dengan ketentuan hukum Allah SWT dan hukum-hukum dibawahnya yang sudah disepakati pada ulama.

Contoh Suku Jawa yang terkenal dengan budaya yang adiluhung, bagaimana nilai-nilai budaya keraton masih sangat dijunjung tinggi meskipun kita sudah berada di kehidupan abad modern secara teknologi dan komunikasi. Wonogiri sebagai kota kelahiran informan, sebuah kota paling selatan dari arah Solo atau Surakarta tempat informan lahir dan mengenyam pendidikan dari sekolah Dasar hingga Sekolah Menengah Atas. Wonogiri secara administrative masih termasuk dalam kekuasaan pemerintah eks karesidenan Surakarta. Sehingga nuansa budaya dan perilaku sosial masyarakat masih sangal kental dengan tradisi budaya Jawa. Surakarta sebagai pusat yang sangat dipengaruhi oleh keberadaan keraton Kasunanan Surakarta yang masih diakui eksistensinya hingga saat ini di masyarakat.

Dalam praktik bahasa, meskipun hidup ditengah kehidupan modern tetapi tata krama bahasa masih diimplentasikan dalam prilaku bahasa di kalangan masyarakat Jawa. Belum lagi tentang adab berbusana, acara ritual pernikahan, kelahiran dan kematian yang masih belum dapat meninggalkan tradisi di Jawa. Orientasi budaya akan menginspirasi informan dalam menentukan isi media massa.

Melihat riwayat lahir, sekolah, kuliah dan juga nama informan menggambarkan bagaimana informan dilingkupi budaya nasionalis, atau yang berorientasi dengan ideology nasionalis. Karena Jawa Tengah adalah basisnya para nasionalis. Sejarah membuktikan bahwa tampuk kepemiminan Jawa Tengah baik di ranah propinsi maupun di ranah kabupaten dan kotamadya dari periode ke periode di menangkan 
oleh kalangan nasionalis. Artinya masyarakat menginginkan bahwa Ideologi nasionalis ini lebih tepat dijalankan di Jawa Tengah. Dan sebagian masyarakat memang tetap loyal atau setia dengan paham nasionalis ini. Pemikiran nasionalis diwariskan oleh para orang kepada anak-anak mereka dengan berbagai macam cara.

Salah satunya adalah dengan pemberian nama, nama adalah citacita orang tua kepada anak di masa depan. Meskipun Ir Soekarno, proklamator Indonesia dan sekaligus Presiden Indonesia Pertama, pencetus ideology nasionalis pernah berkata apalah arti sebuah Nama, namun pada kenyataannya melalui pemberian nama kepada seorang anak dapat diketahui dan dipahami "siapa" dan "bagaimana" orang tua si anak. Termasuk dalam hal ini orientasi ideologi pemberi nama atau orang tua. Selain melalui nama, pemilihan tempat sekolah, pemilihan tempat kuliah juga menentukan anak kuliah atau tidak kuliah, ikut menentukan bagaimana sebenarnaya karakter dan visi orang tua kepada anaknya.

\section{Pemahaman kapitalisme}

Kapitalisme adalah budaya dunia yang mengajarkan kepada pengikutnya untuk mendasarkan padaa pemikiran bahwa penumpukan modal, akumilasi uang dapat digunakan untuk sarana kemakmuran rakyat. Ambisinya adalah bagaimana selalu menggandakan dan meningkatkan nilai modal atau capital disepanjang waktu agar kelak semua manusia dapat hidup senang. Pemikiran ini sejalan dengan pemikiran kaum pedagang, kaum produksen atau mereka yang menyandarkan hidupnya pada sektor distribusi komoditi. Informan yang berpendidikan tinggi memahami hal tersebut. Kajian tentang komunikasi, teori, media, teks media, media dan anak, dan aspek basic komunikasi itu sendiri dimaknai dengan pemahaman kapitalisme ini. Informan yang pernah kuliah diberi pemahaman bahwa ada isme-isme dunia dengan kajian plus minus yang melingkupinya.

Iklan sebagai produk media massa adalah agen kapitalis. Iklan secara sadar atau tidak sadar, secara langsung atau tidak langsung, secara tersurat maupun tersirat telah ikut menyebarkan isme kapitalis ini kepada seluruh khalayaknya. Kreatifitas iklan dalam bentuk gambar, suara, pesan iklan secara audio, visual dan audio visual adalah panjang tangan kapitalis dalam menyebarkan ismenya. Masalahnya jika kapitalisme hanya di adopsi pemahamannya dalam ranah penumpukan modal da nada kegiatan eksploitasi kelas atas kepada kelas tertindas itu adalah kondisi yang sangat berbahaya.

Kapitalisme dalam ranah isi media massa tidak harus dimaknai sebagai pesan negative. Kapitalisme bisa dimaknai positif manakala mampu memotivasi individu untuk erkegiatan ekonomi, melakukan aktifitas berniaga, mendatangkan kemakmuran sehingga membangun kemandirian. Apabila isme ini dimaknai sepihak dengan hura-hura, kelimpahan, kebaruan, egoisme, individualism maka lebih berdampak negative di masyarakat.

Tayangan iklan dengan pesan kapitalis pada produk anak-anak tentu tidak mampu dipahami oleh anakanak.

4. Pemahaman kapitalisme dan budaya dunia.

Individualism, materialism, liberalism adalah budaya dunia yang sedang menguasai pemikiran global saat ini. Budaya individualism muncul dalam iklan dalam episode atau adegan kemenangan, menciptakan anak bersikap individu, mementingkan ego dan berpikir kepentingan individu. 
Gambaran ini tampil pada tayangan iklan dengan cara yang sangat lembut dan mungkin tidak disadari oleh pemirsanya. Misalnya dalam tayangan iklan anak produk makanan dan minuman. Anak ditampilkan selalu nomor satu, lebih cerdas dan lebih unggul dibanding teman-nya setelah ia mengkonsumsi produk makanan atau minuman tertentu.

Liberalism, atau isme kebebasan digambarkan dalam tayangan iklan anak dengan kehidupan yang bebas, berpetualang, menikmati kebebasan alam, anti mainstream dan demokratis. Dalam iklan ditampilkan bagaimana sejak anak-anak sudah digambarkan menyukai kebebasan, bergembira dialam bebas, baik bebas digambarkan secara fisik atau dalam kebebasan berkomunikasi yang demokratis.

Budaya materialism muncul pada tayangan yang menonjolkan aspek kebendaan. Seperti lokasi yang dianggap prestis, menarik, eksotik, tempat, gedung, fashion, make up, assesoris, perhiasan dan lain-lain yang pada intinya adalah materi. Iklan menayangkan aspek bentuk unsur materialism pada iklan anak, dalam segala jenis. Seperti gambaran anak dikaitkan dengan budaya pantai, hura-hura, kelimpah ruahan dan kecukupan materi. Tayangan yang tak kalah penting dalam materialism adalah tampilan fisik kecantikan dan kesempurnaan fisik yang sudah disuarakan sejak dini pada iklan anakanak.

Informan memahami dengan jelas dan akurat tentang isme-isme ini. Tentu bukan merupakan faktor kesengajaan karena praktisi periklanan bekerja berdasarkan tuntutan beberapa pihak, seperti pengiklan, pemiliki produk, idealisme industry dan kreatifitas departemen periklanan yang diputuskan melalui brainstrorming dalam tim kerja departemen kreatif.
Penggunaan bahasa Internasional dalam segala ranah komunikasi adalah upaya bagaiamana agar budaya dunia menjadi milik global. Bahasa inetrnasionala yang dimaksud adalah bahasa Inggris. Bahasa inggris disepakati sebagai bahasa inernasional yang dipakai sebagai bahasa komunikasi antara Negara di dunia.

Penggunanaan bahasa inernasional menjadi rancu atau biasa manakala bahasa intenasional diginakan sebagai bahasa pengantar atau untuk menyampaikan pesan iklan pada pesan komersial produk atau jasa yang merupakan produk nasional atau produk local. Sedangkan tayanganiklan tersebut disamapikan dengan target market dan target audiens nasional. Pemakaian bahasa internasional dalam penyampian pesan iklan sudah dipaksakan dan menjadi keluar dari konteks semula iklan nasional unguk target dan menggunakan media nasional.

Pemaksaan budaya global berdampak buruk pada tercabutnya nilai-nilai kearifan local. Nilai budaya local dalam hal sopan santun, dekat dengan alam dan natural, telah berubah menjadi budaya instan. Disisi lain tuntutan budaya internasional mengharuskan anak dan generasi muda menguasai bahasa asing karemna di masa depan mereka akan bergaul dengan kehidupan internasional. Pembekalan bahasa asing sejak dini patut di milikinya.

5. Pemahaman nilai Islam dalam iklan :

Islam mengajarkan kepada umat dalam ranah individu dan ranah sosial secara proporsional. Dalam berhubungan dengan Allah SWT (Hablumminnalloh), Islam mengajarkan untuk individual, mengerjakan ibadah dan niat baik hanya diperuntukkan kepada Allah SWT tanpa pamrih apapun. Unsur 
kualitas individu menjadi penting ketika individu dituntut senantiasa ikhlas.

Dalam ranah hubungan antar manusia (Hablumminannas) Islam mengajarkan agar keduanya diliputi niat yang baik. Berkomunikasi dengan baik, dengan prinsip qoulan saddidan, qoulan kariman, qoulan makrufan, dan qoulan balighon. Pada prinsipnya adalah berkata yang baik, yang mulia, yang lemah lembut, yang fasih agar pesan yang disampaikan dipahami secara positif oleh penerimanya.

Informan sebagai seorang muslim memahami akan hal ini sehingga prinsip aqidah yang diperoleh sejak sekolah dasar, prinsip berkomunikasi dalam Islam mewarnai informan dalam berkarya. Namun tidak semua insan departemen kreatif memiliki pemahaman tersebut, karena pasti lahir dan tumbuh di lingkungan yang berbeda. Jadi akan kembali kepada kualitas individu dan industry yang bersangkutan.

\section{Pandangan creative departemen tentang kreatifitas iklan.}

Dipandang dari nilai-nilai Islam, Nabi mengajarkan kita untuk berlaku kreatif, laki-laki dan perempuan diperlakukan beda. Baik itu dalam ketentuan jumlah kambing Aqiqoh, Jumlah warisan yang terimakan dan jumlah saksi dalam peradilan. Nabi SAW mengajarkan syiar Islam, yang dalam praktiknya menyruh umatnya menggunakan jalan yang berbeda ketika menuju dan pulang dari pelaksanaan sholat Ied. Demikian juga memakai pakaian terindah yang beda dari digunakan sehari-hari ketika sholat dan hari raya. Namun Nabi juga mengajarkan yang tidak kreatif, artinya sudah ada tauladan contoh dalam pelaksanaan ibadah dengan Alloh SWT. Ada pekerjaan yang sudah ada tuntunannya jika tidak berdasarkan tuntunan maka tidak syah. Tetapi ada pekerjaan yang bisa dikerjakan dengan kreatifitas manusia seperti dalam pelaksanaan ibadah sesama manusia. Disinilah dikatakan bahwa kreatifitas itu ada batasnya. Dimana batas-batas tersebut adalah unuk kebaikan kepada masyarakat.

Dalam hal ini media massa atau iklan sebagai produk media massa melakukan fungsi untuk korelasi sosial seperti ditulis oleh Charles R Wright dan ditekankan oleh Nurudin bahwa media harus mampu menghubungkan berbagai kepentingan di antara lapisan masyarakat yang berbeda dan memiliki kepentingan sendiri-sendiri. Disini media massa berperan menjelaskan, menegaskan aneka kepentingankepentingan yang berbeda tersebut agar dipahami dan disadari oleh semuannya.

\section{Iklan yang baik menurut} departemen creative

Iklan yang baik adalah iklan yang dapat menyampaikan aspek komunikasi yang menjadi tujuannya. Dalam komunikasi suatu proses komunikasi dikatakan efektif apabila tercapai Commoness atau kesamaan makna. Begitupun pada cabang komunikasi yaitu iklan maka iklan yang baik adalah iklan yang dapat dipahami maknanya seperti apa yang diinginkan oleh pemasang iklan. Adapun berbagai kreatifitas yang saling berbeda dalam menyampaikan pesan hanya merupakan metode. Pada prinsipnya komunikasi dilakukan antar manusia untuk mencapai persamaan dengan orang lain ( Willbur Schramm, dalam Effendy, 2004) Senada dengan Schramm, adalah pendapat Everet M. Rogers, komunikasi adalah suatu proses dimana ide dialihkan dari sumber kepada suatu penerima atau lebih dengan maksud untuk mengubah tingkah laku. Sedangkan Gerald R. Miller menyaakan bahwa komunikasi terjadi ketika suatu 
sumber menyampaikan suatu pesan kepada penerima dengan niat yang disadari untuk mempengaruhi perilaku penerima. Pendapat ini disetujui oleh Carld R. Miller mengatakan bahwa komunikasi adalah proses yang memungkinkan seseorang (komunikator) menyampaikan rangsangan (biasanya lambinglambang verbal) untuk mengubah perilaku atau yang lain. Adapun Theodore M Newcomb menekankan bahwa setiap tindakan komunikasi dipandang sebagai suatu transmisi informasi terdiri dari rangsangan yang diskriminatif dari sumber kepada penerima. Didukung keterangan para pakar komunikasi tersebut maka dapat dikatakan bahwa sebagai kegiatan komunikasi iklan mengalami proses menampaikan sesuatu.

Iklan dikatan baik atau iklan yang efektif haruslah jika mampu mengkomunikasikan ide-ide berupa lambang-lambang yang dipahami dan terjadi mutual understanding dari komunikator dan komunikannya. Pesan iklan harus dimaknai oleh audiensnya sama seperti yang apa yang inginkan komunikator. Pernyataan ini diperkuat oleh pendapat Stewart L. Tubbs dan Sylvia Moss bahwa komunikasi adalah proses pembentukan makna diantara dua orang atau lebih. Pendapat yang hamper sama disampaikan oleh Judy C, Pearson dan Paul E. Nelson, yang mengatakan komunikasi adalah proses memahami dan berbagi makna. Semntara itu William I. Gordon mendukung keduanya dengan menyatakan bahwa komunikasi adalah suatu transaksi dinamis yang melibatkan gagasan dan perasaan. Demikian juga Donald Byker dan Loren J. Anderson mengemukakan bahwa komunikasi adalah berbagi informasi antara dua orang atau lebih.

\section{SIMPULAN DAN SARAN}

Pada akhir penelitian ini yang berjudul Kapitalisme, Budaya Dunia dan Nilai-Nilai Islam pada Tayangan iklan anak di Televise dalam Perspektif Departemen Kreatif Industri Periklanan yang dikaji secara kualitatif deskriptif menghasilkan kesimpulan sebagai berikut.

1. Dalam merancang karya iklan, insan departemen kreatif tidak pernah ada unsur kesengajaan memasukkan pesan-pesan iklan yang bermuatan kapitalisme, budaya dunia dan nilainilai Islam dalam karya iklannya.

2. Unsur kreatifitas adalah unsur utama yang menjadi pertimbangan insan dan tim kerja departemen kratif dalam menyusun rancangan karya iklan.

3. Dalam merancang pesan iklan, insan departemen kreatif tidak bekerja sendiri tetapi hasil diskusi dengan tim departemen kreatif, art director dan pengiklan.

4. Secara tidak langsung faktor-faktor individual insan departemen kreatif industry periklanan turut berperanan dalam menciptakan pesan iklan yang mengandung muatan kapitalisme, budaya dunia dan nilai-nilai Islam pada tayangan iklan anak di media televisi.

5. Secara tidak langsung faktor organisasi media dalam industri periklanan turut berperanan dalam menciptakan pesan iklan yang mengandung muatan kapitalisme, budaya dunia dan nilainilai Islam pada tayangan iklan anak di media televisi.

6. Secara tidak langsung faktor ekstra media dari lingkungan industri periklanan turut berperanan dalam menciptakan pesan iklan yang mengandung muatan kapitalisme, budaya dunia dan nilai-nilai Islam pada tayangan iklan anak di media televisi. 


\section{E. SARAN}

Adapun saran yang dapat peneliti sampaikan berkaitan dengan hasil penelitian adalah sebagai berikut:

1. Kualitas individu sangat berperanan dalan kreatif penciptaan iklan di dalam industry periklanan. Oleh karenanya pemahaman tentang agama, keyakinan, ideology dan politik menjadi penting dalam upaya penciptaan pesan iklan yang etis.

2. Pendidikan media bagi masyarakat khususnya orang tua dan guru perlu terus menerus dilakukan sesuai perkembangan teknologi media.

3. Penguatan kecerdasan spiritual, sosial, keilmuan dikalangan akedemik untuk menyiapkan sumber daya manusia di media yang kualified.

4. Penguatan sisi etis pada calon sumber daya media di industry Ilmu Komunikasi.

\section{DAFTAR PUSTAKA}

Al Qur'anul Karim

Agus S, Madjadikara,(2005), Bagaimana Biro Iklan Memproduksi Iklan, Jakarta, PT Gramedia Pustaka Utama.

Budiman Hakim, (2008), Ngobrolin Iklan

Yuk, Second Edition, Yogyakarta, Galang Press.

Deddy Mulyana, (1996), Etika Komunikasi, Bandung, Remaja Rosdakarya.

Denis McQuail,(2002), Mass Communication Theory,London, Sage Publications..

Edward De Bono, (2004) Thingking Course, BBC Books.

\section{(2015) Simplicity, Peguin}

Littlejohn, W, Stephen, ( 2001), Theories of Human Communication, Albuquerque, New mexico.

Marhaeni, Dian, (Dkk), (2005), Komunikasi, Perubahan Sosial dan Dehumanisasi, Surakarta, Penerbit Pustaka Rumpun Ilalang
Dian, (2006), Wacana kapitalis pada Iklan anak-anak di Media Televisi, Analisis Wacana, Thesis, UNS Surakarta

-, Dian, Iklan dan Situs Internet, Kreatif dan Strategi periklanan di Media Internet, Wahana Ilmiah Vol I Nomor 1 Tahun 2003

-, Dian, Fenomena Dehumanisasi Anak pada Iklan Televisi, Publica, Vol IV Nomor 2 Tahun 2008

Mc Quail, Denis,(1987), Teori Komunikasi Massa, Suatu Pengantar, edisi kedua, Jakarta, Penerbit Erlangga.

Monie Lee, Carla Johnson, ((2013), A Global Perspektif, Second Edition.

Oliver Boyd-Barrett, and Chris Newbold, ( 1995), Approaches to Media A Reader, Great Britain, Gray Publitsing.

Rhenald Kasali, (1992). Manajemen Periklanan, Konsep dan Aplikasinya di Indonesia, Jakarta, Pustaka Utama Grafiti.

Sutopo, H.B. (2002), Metodologi Penelitian Kualitatif, Surakarta, Universitas Sebelas Maret Press.

Yin, R.K. (1987), Case Study Research: Design And Methods. Beverly Hills CA.: Sage Publications.

Ibnu Hamad, (2004) Kontruksi Realitas Politik Dalam Media Media Massa: Sebuah Studi Critical, Jakarta, Yayasan Obor. 